\title{
Importance of Discriminative Measurement for Radon Isotopes and Its Utilization in the Environment and Lessons Learned from Using the RADUET Monitor
}

\author{
Chutima Kranrod ${ }^{1,2,+}+$, , Yuki Tamakuma ${ }^{1,3,+}$, Masahiro Hosoda ${ }^{1,3}$ (D) and Shinji Tokonami ${ }^{1, *(1)}$ \\ 1 Institute of Radiation Emergency Medicine, Hirosaki University, Hirosaki, Aomori 036-8564, Japan; \\ kranrodc@hirosaki-u.ac.jp (C.K.); tamakuma@hirosaki-u.ac.jp (Y.T.); m_hosoda@hirosaki-u.ac.jp (M.H.) \\ 2 Natural Radiation Survey and Analysis Research Unit, Department of Nuclear Engineering, Faculty of \\ Engineering, Chulalongkorn University, Bangkok 10330, Thailand \\ 3 Graduate School of Health Sciences, Hirosaki University, Hirosaki 036-8564, Aomori, Japan \\ * Correspondence: tokonami@hirosaki-u.ac.jp; Tel.: +81-17-239-5404 \\ + These authors made equal contributions to the paper.
}

Received: 30 April 2020; Accepted: 9 June 2020; Published: 10 June 2020

\begin{abstract}
Radon $\left({ }^{222} \mathrm{Rn}\right)$ and thoron $\left({ }^{220} \mathrm{Rn}\right)$, sources of natural background radiation, have been the subjects of long-standing studies, including research into radon and thoron as major causes of lung cancer at domestic and international levels. In this regard, radon and thoron measurement studies have been widely conducted all over the world. Generally, the techniques used relate to passive nuclear track detectors. Some surveys have shown that passive monitors for radon are sensitive to thoron, and hence some measured results have probably overestimated radon concentrations. This study investigated radon and thoron measurements in domestic and international surveys using the passive radon-thoron discriminative monitor, commercially named RADUET. This paper attempts to provide an understanding of discriminative measurements of radon isotopes and to present an evidence-based roadmap.
\end{abstract}

Keywords: radon-thoron discrimination; RADUET; radon; thoron

\section{Introduction}

Radon $\left({ }^{222} \mathrm{Rn}\right)$ is a noble gas generated from materials including radium $\left({ }^{226} \mathrm{Ra}\right)$ (a decay product of uranium $\left({ }^{238} \mathrm{U}\right)$ ) such as rocks, soil, water and building materials. Radon is well known as the second leading cause of lung cancer after tobacco smoking [1]. According to an epidemiological investigation by Darby et al. [2], consecutive exposure to $100 \mathrm{~Bq} \mathrm{~m}^{-3}$ of radon results in a $16 \%$ excess relative risk of lung cancer. The World Health Organization recommended that a radon concentration of $100 \mathrm{~Bq} \mathrm{~m}^{-3}$ should be used as a national reference value and stated that this value was justified from a public health effect perspective [1]. Even if it cannot be implemented, the chosen reference level should not exceed $300 \mathrm{~Bq} \mathrm{~m}^{-3}$ which corresponds to $10 \mathrm{mSv}$ of effective doses per year based on the calculations by the International Commission on Radiological Protection (ICRP) [3]. The ICRP also encouraged use of the reference level of $100-300 \mathrm{~Bq} \mathrm{~m}^{-3}$ [4]. Besides this, a new dose conversion factor for radon was proposed by the ICRP [5] according to the latest epidemiological studies and a dosimetric model, and this factor is approximately two times higher than the commonly used value of the United Nations Scientific Committee on the Effects of Atomic Radiation (UNSCEAR) [6]. Thus, it is increasingly important to accurately measure radon and to evaluate the dose attributed to radon and its progenies from the viewpoint of radiation protection for humans. 
Many radon surveys have been conducted in countries all over the world to investigate radon levels [7-13]. Generally, passive radon monitors are used for large-scale surveys because their operation is quiet and low-cost. However, it has been reported that some have a high sensitivity to thoron $\left({ }^{220} \mathrm{Rn}\right)$, which is a radioisotope of radon, and the measurement results might have been affected by the existence of thoron [14-16]. Passive radon monitors which had been shown to have a high sensitivity to thoron were used for a nationwide radon survey in some countries [8-10,17]. It is necessary to pay attention to those reports in which the possible presence of thoron would significantly bias results for radon measurements. From the viewpoint of radiation protection, thoron has been historically ignored because of its half-life (55.6 s) and difficulties in measurement and calibration. It should be noted, however, that the quantity of thoron can be larger than that of radon in some areas, for example in Yangjang, China [18]. If a passive radon monitor cannot discriminatively measure radon and thoron, measurement results will be overestimated, and they cannot be corrected due to no significant relationship between radon and thoron concentrations $[15,19]$. Therefore, radon and thoron should be discriminatively measured for an accurate dose assessment and for future lung cancer risk assessment due to indoor radon [6].

This article presents a summary of the passive radon-thoron discriminative monitors known as RADUET and their applications in studies worldwide.

\section{Summary of RADUET}

The RADUET is a passive integrated radon-thoron discriminative monitor, which was developed by Tokonami et al. [20]. Schematic drawings of the RADUET monitor are shown in Figure 1. It has double plastic chambers with different air-exchange rates or air-diffusion rates. A CR-39 (the allyl diglycol carbonate) detector, which is used to detect alpha particles emitted from radon, thoron and their progenies, is placed at the bottom of each chamber with sticky clay. The low air-exchange rate chamber is made of electro-conductive plastic with an inner volume of $\sim 3.0 \times 10^{-5} \mathrm{~m}^{3}$. The high air-exchange rate chamber is also made of the same plastic material, but it has six holes in the wall and has an electroconductive sponge covering the holes to prevent radon and thoron decay products and aerosols from going into the chamber. Thus, radon gas can diffuse into the low air-exchange rate chamber through an invisible gap between the lid and the bottom of the chamber. Subsequently, this gap functions as a high air-diffusion rate barrier; due to its very short half-life (55.6 s), only a very small amount of thoron goes into the chamber compared to the amount for radon with a longer half-life $(3.82 \mathrm{~d})$. Additionally, both radon and thoron can get into the high air-exchange rate chamber. The air-exchange rates of the low and high air-diffusion rate chambers are $0.7 \mathrm{~h}^{-1}$ and $10 \mathrm{~h}^{-1}$, respectively [21]. The air-exchange rates of RADUET chambers differ by about two orders of magnitude. Correspondingly, the difference of track density between the two CR-39s detectors from each chamber makes it possible to discriminate between radon and thoron.

For analysis of the CR-39 detectors from the RADUET, they are chemically etched in concentrated base solution according to the manufacturers' protocols. For example, CR-39 detectors manufactured by Radosys Ltd. (Budapest, Hungary) have to be etched with a $6.25 \mathrm{M} \mathrm{NaOH}$ solution at $90{ }^{\circ} \mathrm{C}$ for $6 \mathrm{~h}$, while CR-39 detectors manufactured by Nagase Landauer, Ltd. (Ibaraki, Japan) have to be etched with a $6 \mathrm{M} \mathrm{NaOH}$ solution at $60^{\circ} \mathrm{C}$ for $24 \mathrm{~h}$. After that, the tracks formed on CR-39 are counted with an automatic reading system or optical microscope and image software. For calculating radon and thoron concentrations, the obtained total track densities are replaced into the following equations [22]:

$$
\begin{gathered}
\bar{C}_{\mathrm{Rn}}=\left(d_{\mathrm{L}}-\bar{b}\right) \times \frac{f_{\mathrm{Tn} 2}}{t \times\left(f_{\mathrm{Rn} 1} \times f_{\mathrm{Tn} 2}-f_{\mathrm{Rn} 2} \times f_{\mathrm{Tn} 1}\right)}-\left(d_{\mathrm{H}}-\bar{b}\right) \times \frac{f_{\mathrm{Tn} 1}}{t \times\left(f_{\mathrm{Rn} 1} \times f_{\mathrm{Tn} 2}-f_{\mathrm{Rn} 2} \times f_{\mathrm{Tn} 1}\right)} \\
\bar{C}_{\mathrm{Tn}}=\left(d_{\mathrm{H}}-\bar{b}\right) \times \frac{f_{\mathrm{Rn} 1}}{t \times\left(f_{\mathrm{Rn} 1} \times f_{\mathrm{Tn} 2}-f_{\mathrm{Rn} 2} \times f_{\mathrm{Tn} 1}\right)}-\left(d_{\mathrm{L}}-\bar{b}\right) \times \frac{f_{\mathrm{Rn} 2}}{t \times\left(f_{\mathrm{Rn} 1} \times f_{\mathrm{Tn} 2}-f_{\mathrm{Rn} 2} \times f_{\mathrm{Tn} 1}\right)}
\end{gathered}
$$


where $\bar{C}_{\mathrm{Rn}}$ and $\bar{C}_{\mathrm{Tn}}$ are the mean concentrations of radon and thoron during the exposure period in $\mathrm{Bq} \mathrm{m}{ }^{-3} \cdot d_{\mathrm{L}}$ and $d_{\mathrm{H}}$ are the total alpha track densities (track $\mathrm{m}^{-2}$ ) taken from the CR-39 detectors of low and high air-exchange rate chambers. $f_{\mathrm{Rn} 1}$ and $f_{\mathrm{Tn} 1}$ are the radon and thoron calibration coefficients for the low air-exchange rate chamber in tracks $\mathrm{m}^{-2} \mathrm{kBq}^{-1} \mathrm{~m}^{3} \mathrm{~h}^{-1} \cdot f_{\mathrm{Rn} 2}$ and $f_{\mathrm{Tn} 2}$ are the radon and thoron calibration coefficients for the high air-exchange rate chamber in tracks $\mathrm{m}^{-2} \mathrm{kBq}^{-1} \mathrm{~m}^{3} \mathrm{~h}^{-1} . t$ is the exposure time in hours and $b$ is the background track density of the CR-39 detector in tracks $\mathrm{m}^{-2}$.
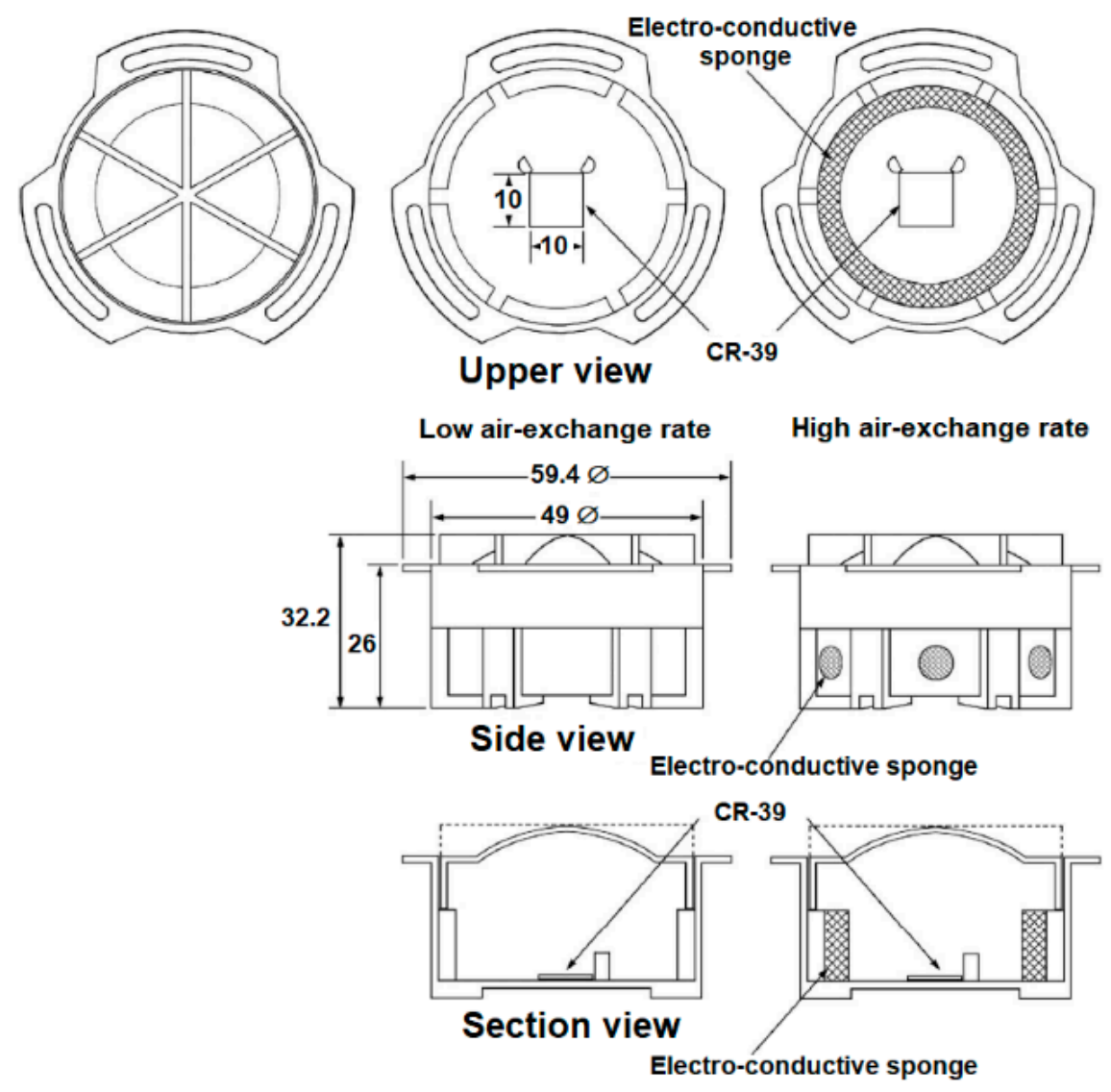

Figure 1. Schematic views of the RADUET monitor (unit: $\mathrm{mm}$ ).

It should be noted that the low air-exchange rate chamber limits diffusion of thoron into the chamber, therefore, $f_{\mathrm{Rn} 1}>>f_{\mathrm{Tn} 1}$. The high air-exchange rate chamber is designed such that both radon and thoron can diffuse into the chamber easily, and $f_{\mathrm{Rn} 2} \sim f_{\mathrm{Tn} 2}$.

To determine the calibration coefficients, RADUETs should be calibrated at a reference laboratory. The calibration coefficients are estimated by a correlation between the track density and the time-integrated radon and thoron concentrations from three or four exposure levels of radon and thoron [23]. In the calibration procedure of the radioactive gas monitor, most RADUET monitors are calibrated using a secondary method based on a calibration via a reference monitor. Thus, five to ten monitors, depending on the size of the calibration chamber, are placed in the middle of the chamber for each reference exposure condition. The introduction level of radon and thoron in each calibration chamber should be assigned to three or four different levels for the time-integrated radon and thoron concentrations such as $\sim 500 \mathrm{kBq} \mathrm{h} \mathrm{m}^{-3}, \sim 1000 \mathrm{kBq} \mathrm{h} \mathrm{m}^{-3}, \sim 2000 \mathrm{kBq} \mathrm{h} \mathrm{m}^{-3}$ and $\sim 3000 \mathrm{kBq} \mathrm{h} \mathrm{m}^{-3}$. These calibrations are intended to obtain traceability to primary standards of radon isotopes and to test linearity of monitor response over the whole range of interest of exposure values. Throughout the calibration experiments, concentration of radon isotopes in the chamber is continuously monitored with active measurement equipment which has itself been compared with a standard for radon isotopes. Moreover, environmental parameters, such as humidity, pressure and temperature in the 
calibration chamber should be continuously measured and constantly observed. After exposure, the CR-39 detectors from RADUET are chemically etched and afterwards the number of tracks on the CR-39 is counted as used for measurement samples. In addition, the background noise from five or ten CR-39 detectors that have not been exposed to radon and thoron and have been processed under the same chemical etching and counting conditions are measured at the same time as the calibration. Subsequently, the four calibration curves are plotted as the time-integrated radon or thoron exposure (on the $\mathrm{X}$ axis) versus the track density (on the $\mathrm{Y}$ axis) for the high and low air-exchange rates of RADUET. Thus, $f_{\mathrm{Rn} 1}, f_{\mathrm{Tn} 1}, f_{\mathrm{Rn} 2}$ and $f_{\mathrm{Tn} 2}$ are given by fitting each calibration curve using linear regression [20]. The slope of the linear line of each calibration curve is the calibration coefficient or calibration factor between the density of the tracks per unit of time (tracks $\mathrm{m}^{-2} \mathrm{~h}^{-1}$ ) and the activity concentration $\left(\mathrm{kBq} \mathrm{m}^{3}\right)$ of the reference atmosphere.

Moreover, based on the fact of the RADUET that concentration in one chamber depends on the other, the calculation procedure for the decision threshold and detection limits are estimated in the following manner [22]. The decision thresholds of the average radon concentration $\left(\bar{C}_{\mathrm{Rn}}^{*}\right)$ and the average thoron concentration $\left(\bar{C}_{\mathrm{Tn}}^{*}\right)$ are obtained from Equations (1) and (2) and their standard uncertainty for $\widetilde{C}_{\mathrm{Rn}}=0, \widetilde{u}\left(d_{\mathrm{L}}\right)=0, \widetilde{C}_{\mathrm{Tn}}=0$ and $\widetilde{u}\left(d_{\mathrm{H}}\right)=0$. These yield Equations (3) and (4). (It should be noted that $\alpha=0.05$ and $\mathrm{k}_{1-\alpha}=1.65$ are often selected by default.)

$$
\begin{aligned}
& \bar{C}_{\mathrm{Rn}}^{*}=\mathrm{k}_{1-\alpha} \cdot \widetilde{u}(0)=\mathrm{k}_{1-\alpha} \sqrt{\begin{array}{c}
\omega_{1}^{2} u^{2}(\bar{b})-2 \omega_{1} \omega_{2} u^{2}(\bar{b})+\omega_{2}^{2}\left(u^{2}\left(d_{\mathrm{H}}\right)+u^{2}(\bar{b})\right)+\frac{\left(d_{\mathrm{H}}^{2}-2 \bar{b} d_{\mathrm{H}}+\bar{b}^{2}\right) \omega_{2}^{2}}{\omega_{1}^{2}} u^{2}\left(\omega_{1}\right) \\
+\left(-d_{\mathrm{H}}+\bar{b}\right)^{2} u^{2}\left(\omega_{2}\right)
\end{array}} \\
& \bar{C}_{\mathrm{Tn}}^{*}=\mathrm{k}_{1-\alpha} \cdot \widetilde{u}(0)=\mathrm{k}_{1-\alpha} \sqrt{\begin{array}{c}
\omega_{3}^{2} u^{2}(\bar{b})-2 \omega_{3} \omega_{4} u^{2}(\bar{b})+\omega_{4}^{2}\left(u^{2}\left(d_{\mathrm{L}}\right)+u^{2}(\bar{b})\right)+\frac{\left(d_{\mathrm{L}}^{2}-2 \bar{b} d_{\mathrm{L}}+\bar{b}^{2}\right) \omega_{4}^{2}}{\omega_{3}^{2}} u^{2}\left(\omega_{3}\right) \\
+\left(-d_{\mathrm{L}}+\bar{b}\right)^{2} u^{2}\left(\omega_{4}\right)
\end{array}}
\end{aligned}
$$

The detection limit of the average radon $\left(\bar{C}_{R n}^{\#}\right)$ and thoron concentration $\left(\bar{C}_{T n}^{\#}\right)$ are calculated as given in Equations (5) and (6). (It should be noted that $\alpha=\beta=0.05$ and $\mathrm{k}_{1-\alpha}=\mathrm{k}_{1-\beta}=1.65$ are often selected by default.)

$$
\begin{aligned}
& \bar{C}_{\mathrm{Rn}}^{\#}=\bar{C}_{\mathrm{Rn}}^{*}+\mathrm{k}_{1-\beta} \cdot \bar{u}\left[\bar{C}_{\mathrm{Rn}}^{\#}\right]=\bar{C}_{\mathrm{Rn}}^{*}+\mathrm{k}_{1-\beta} \sqrt{\begin{array}{c}
\omega_{1}^{2}\left[u^{2}\left(d_{\mathrm{L}}\right)+u^{2}(\bar{b})\right]-2 \omega_{1} \omega_{2} u^{2}(\bar{b})+\omega_{2}^{2}\left[\left(u^{2}\left(d_{\mathrm{H}}\right)+u^{2}(\bar{b})\right]\right. \\
+\frac{\left(d_{\mathrm{H}}^{2}-2 \bar{b}_{\mathrm{H}}+\bar{b}^{2}\right) \omega_{2}^{2}+\widetilde{C}_{\mathrm{Rn}}\left(2 d_{\mathrm{H}}-2 \bar{b}\right) \omega_{2}+\widetilde{C}_{\mathrm{Rn}}^{2}}{\omega_{1}^{2}} u^{2}\left(\omega_{1}\right)+\left(-d_{\mathrm{H}}+\bar{b}\right)^{2} u^{2}\left(\omega_{2}\right)
\end{array}} \\
& \bar{C}_{\mathrm{Tn}}^{\#}=\bar{C}_{\mathrm{Tn}}^{*}+\mathrm{k}_{1-\beta} \cdot \vec{u}\left[\overline{\mathrm{C}}_{\mathrm{Tn}}^{\#}\right]=\overline{\mathrm{C}}_{\mathrm{Tn}}^{*}+\mathrm{k}_{1-\beta} \sqrt{\begin{array}{c}
\omega_{3}^{2}\left[u^{2}\left(d_{\mathrm{H}}\right)+u^{2}(\bar{b})\right]-2 \omega_{3} \omega_{4} u^{2}(\bar{b})+\omega_{4}^{2}\left[\left(u^{2}\left(d_{\mathrm{L}}\right)+u^{2}(\bar{b})\right]\right. \\
+\frac{\left(d_{\mathrm{L}}^{2}-2 \bar{b} d_{\mathrm{L}}+\bar{b}^{2}\right) \omega_{4}^{2}+\widetilde{C}_{\mathrm{Tn}}\left(2 d_{\mathrm{L}}-2 \bar{b}\right) \omega_{4}+\widetilde{C}_{\mathrm{Tn}}^{2}}{\omega_{1}^{2}}
\end{array} u^{2}\left(\omega_{3}\right)+\left(-d_{\mathrm{L}}+\bar{b}\right)^{2} u^{2}\left(\omega_{4}\right)}
\end{aligned}
$$

Here $\omega_{1}=\frac{f_{\mathrm{Tn} 2}}{t\left(f_{\mathrm{Rn} 1} \cdot f_{\mathrm{Tn} 2}-f_{\mathrm{Rn} 2} \cdot f_{\mathrm{Tn} 1}\right)}, \quad \omega_{2}=\frac{f_{\mathrm{Tn} 1}}{t\left(f_{\mathrm{Rn} 1} \cdot f_{\mathrm{Tn} 2}-f_{\mathrm{Rn} 2} \cdot f_{\mathrm{Tn} 1}\right)}, \quad \omega_{3}=\frac{f_{\mathrm{Rn} 1}}{\overline{t\left(f_{\mathrm{Rn} 1} \cdot f_{\mathrm{Tn} 2}-f_{\mathrm{Rn} 2} \cdot f_{\mathrm{Tn} 1}\right)}}$, and $\omega_{4}=\frac{f_{\mathrm{Rn} 2}}{t\left(f_{\mathrm{Rn} 1} \cdot f_{\mathrm{Tn} 2}-f_{\mathrm{Rn} 2} \cdot f_{\mathrm{Tn} 1}\right)} \cdot \widetilde{C}_{\mathrm{Rn}}$ and $\widetilde{C}_{\mathrm{Tn}}$ are the true values of the average radon and thoron concentrations. $\widetilde{u}\left(d_{\mathrm{L}}\right)$ and $\widetilde{u}\left(d_{\mathrm{H}}\right)$ are the standard uncertainties of the estimators of $\widetilde{C}_{\mathrm{Rn}}$ and $\widetilde{C}_{\mathrm{Tn}}$. $\vec{u}\left[\bar{C}_{R n}^{\#}\right]$ and $\vec{u}\left[\bar{C}_{T n}^{\#}\right]$ are the standard uncertainties of detection limits of average radon and thoron concentrations associated with measurement results.

Based on the calculation procedure given above, the detection limits for the typical measurement conditions have been estimated in the literature to be $3 \mathrm{~Bq} \mathrm{~m}^{-3}$ for radon and $14 \mathrm{~Bq} \mathrm{~m}^{-3}$ for thoron [20]. Moreover, the detection limits for the high background area condition have been assessed to be $10 \mathrm{~Bq} \mathrm{~m}^{-3}$ for radon and $20 \mathrm{~Bq} \mathrm{~m}^{-3}$ for thoron [24]. 


\section{Lessons Learned on Radon and Thoron Measurement by the RADUET}

Radon and thoron simultaneous measurements using a passive detector have been carried out for indoor environments in many countries [15,25-29]. The RADUET has been one of the most favored radon and thoron discriminative detectors used for both small and large national surveys. Furthermore, there are many studies using the RADUET for such applications as validation of the scanner-based radon track detector evaluation system [30], radon and thoron exhalation rates from building materials [31] and performance testing of the effects of environmental parameters on passive detectors [32].

This section points out the value of discriminating thoron from radon in measuring radon isotopes by describing regional and national surveys which have been made in various countries.

In China, RADUETs were used to determine the indoor concentrations of radon and thoron at high natural background radiation areas in Yangxi and Yangdong Districts [18,33]. RADUETs were placed at the distance of $\sim 0.3 \mathrm{~m}$ from the wall and $\sim 1.8 \mathrm{~m}$ from the floor. Indoor radon and thoron concentrations were measured for six months at 59 dwellings and wide variations were seen from house to house. The mean indoor radon concentration was $124 \pm 78 \mathrm{~Bq} \mathrm{~m}^{-3}$ (range from $27-476 \mathrm{~Bq} \mathrm{~m}^{-3}$ ) and the mean indoor thoron concentration was $1247 \pm 1189 \mathrm{~Bq} \mathrm{~m}^{-3}$ (range from $65-3957 \mathrm{~Bq} \mathrm{~m}^{-3}$ ). Moreover, these surveys revealed that the significance of thoron had been underestimated in the past [15]. Thus, thoron should be more rigidly defined from the viewpoint of health risk.

In India, RADUETs were used to measure radon and thoron concentrations in 62 dwellings (cement, brick and mud houses) of a high natural background radiation area on the southeastern coast of Odisha and 259 houses (cement and brick, and some wood houses) on the southwest coast of Kerala [34,35]. Detectors were hung $0.2-2.0 \mathrm{~m}$ from the wall and $0.3-1.6 \mathrm{~m}$ from the ceiling in the bedroom or living room and some in the dining room or storeroom. At Odisha, respective radon and thoron concentrations ranged from $2-333 \mathrm{~Bq} \mathrm{~m}^{-3}$ with a mean value of $91 \mathrm{~Bq} \mathrm{~m}^{-3}$ and below the detection limit to $1004 \mathrm{~Bq} \mathrm{~m}^{-3}$ with a mean value of $105 \mathrm{~Bq} \mathrm{~m}^{-3}$. In addition, the respective radon and thoron concentrations at Kerala (two periods of six-month measurements) ranged from 1-21 Bq m${ }^{-3}$ with a mean of $6 \pm 4 \mathrm{~Bq} \mathrm{~m}^{-3}$ and a range of $3-212 \mathrm{~Bq} \mathrm{~m}^{-3}$ with a mean of $31 \pm 13 \mathrm{~Bq} \mathrm{~m}^{-3}$, respectively. These studies showed higher concentrations of thoron in comparison with radon in certain cases.

In Cameroon, a total of 450 RADUETs were used to measure indoor radon and thoron concentrations in houses around mining and ore-bearing regions of Poli, Lolodorf, Betare-Oya and Douala [24,36-39]. The monitors were hung from the ceiling in the bedroom for two months at a height of $1.5-2.0 \mathrm{~m}$ from the floor and $0.5 \mathrm{~m}$ from the wall. The respective indoor radon and thoron concentrations ranged between $46-143$ and $24-238 \mathrm{~Bq} \mathrm{~m}^{-3}$ in Poli, $27-937$ and 6-700 Bq m${ }^{-3}$ in Lolodorf, 88-282 and 4-383 Bq m${ }^{-3}$ in Betare-Oya, and 31-436 and 4-246 Bq m${ }^{-3}$ in Douala. The mean values were 82 and $94 \mathrm{~Bq} \mathrm{~m}^{-3}, 97$ and $160 \mathrm{~Bq} \mathrm{~m}^{-3}, 133$ and $92 \mathrm{~Bq} \mathrm{~m}^{-3}$ and 139 and $80 \mathrm{~Bq} \mathrm{~m}^{-3}$, respectively. The results showed higher concentrations of thoron in comparison with radon in some cases.

In Thailand, indoor radon measurements in dwellings of Chiang Mai were conducted using 110 RADUETs ( 55 houses) during one year where a high number of new cases of lung cancer had been found [40]. All monitors were placed in the selected houses at a height of 1.0-2.0 m and $0.2 \mathrm{~m}$ from the wall in the bedroom for all seasons (two periods of six-month measurements in 2015-2016). The results showed that the mean radon levels varied from 35-209 $\mathrm{Bq} \mathrm{m}^{-3}$, with an overall mean of $57 \pm 2 \mathrm{~Bq} \mathrm{~m}^{-3}$. Moreover, there was no relationship between the indoor radon levels and seasonal variations caused by the influence of climate change as the mean radon activity concentrations showed no significant difference ( $p=0.76$ ) between the two periods of measurement. On the other hand, the results showed there was a lower level of thoron than radon in all the dwellings.

In Japan the third nationwide indoor radon survey was conducted in 2007-2010 [41] at 3461 dwellings (wooden, concrete, other and unknown types), assigned by the Neyman allocation method, using RADUETs. Moreover, the seasonal adjustment for each house type was applied to calculate indoor radon concentrations. The mean indoor radon concentration was $14.3 \pm 14.7 \mathrm{~Bq} \mathrm{~m}^{-3}$. The indoor thoron concentrations were also obtained in this radon survey. However, it is difficult to obtain a 
representative indoor/outdoor thoron concentration because the monitors used for the survey were installed at different distances from the wall surface $[15,42,43]$. Therefore, it should be noted that the main purpose of a radon-thoron discriminative monitor like the RADUET is to reduce the influence of thoron on the radon measurements.

In Kenya, the concentration levels of radon and thoron were measured using 46 RADUETs in mud-walled, metallic- or iron sheet-walled and stone-walled non-traditional houses in the Kilimambogo region [44] and 20 RADUETs in traditional earthen dwellings in the Mrima Hill region [45,46]. The monitors were set in the dwellings for a three-month period at a distance of $\sim 0.2 \mathrm{~m}$ far from the wall and $2.0 \mathrm{~m}$ above the floor. The mean radon concentration levels in mud-walled, metallic-walled and stone-walled non-traditional houses were $67 \pm 11 \mathrm{~Bq} \mathrm{~m}^{-3}$ (ranged: $37-126 \mathrm{~Bq} \mathrm{~m}^{-3}$ ), $60 \pm 10 \mathrm{~Bq} \mathrm{~m}^{-3}$ (ranged: $42-163 \mathrm{~Bq} \mathrm{~m}^{-3}$ ) and $75 \pm 10 \mathrm{~Bq} \mathrm{~m}^{-3}$ (ranged: 38-84 $\mathrm{Bq} \mathrm{m}^{-3}$ ) respectively, while the mean thoron concentration levels in the corresponding non-traditional houses were $195 \pm 36 \mathrm{~Bq} \mathrm{~m}^{-3}$ (range: below the detection limit-973 $\mathrm{Bq} \mathrm{m}^{-3}$ ), $71 \pm 24 \mathrm{~Bq} \mathrm{~m}^{-3}$ (ranged: below the detection limit-1130 $\mathrm{Bq} \mathrm{m}^{-3}$ ) and $161 \pm 31 \mathrm{~Bq} \mathrm{~m}^{-3}$ (ranged: below the detection limit-385 $\mathrm{Bq} \mathrm{m}^{-3}$ ). Moreover, the mean radon concentration in traditional houses was $35 \pm 17 \mathrm{~Bq} \mathrm{~m}^{-3}$ (range: $16-56 \mathrm{~Bq} \mathrm{~m}^{-3}$ ), whereas the mean thoron concentration was $652 \pm 397 \mathrm{~Bq} \mathrm{~m}^{-3}$ (range: $132-1295 \mathrm{~Bq} \mathrm{~m}^{-3}$ ). This implied that if a non-discriminative detector was used, and if doors and windows were closed at night as happens in habited dwellings, the radon levels in the huts would be much higher than reported.

In Australia, long term measurements (70-90 days in spring and winter for seasonal variation) were conducted for radon and thoron using RADUETs in an historical metalliferous underground mine in North Queensland [47]. The discriminative monitors were used as the primary monitors in the 2015 program and as comparison and quality monitors between other passive radon monitors and active monitors in a 2016 program. All monitors were places between 0.05 and $2.5 \mathrm{~m}$ from the mine wall surface. The radon and thoron concentrations ranged between 60 and $390 \mathrm{~Bq} \mathrm{~m}^{-3}$ (mean: $140 \pm 55 \mathrm{~Bq} \mathrm{~m}^{-3}$ ) and 140 and $2600 \mathrm{~Bq} \mathrm{~m}^{-3}$ (mean: $1070 \pm 510 \mathrm{~Bq} \mathrm{~m}^{-3}$ ), respectively. The radon results showed negligible significant variation between sampling periods and the thoron results at the same sampling locations showed the same trends for both seasons. However, the thoron data in places of high thoron concentration fluctuated according to the monitor placement at different distances from the exhalation surface (wall). Thus, the optimal sampling distance for thoron should be below $0.5 \mathrm{~m}$ from the wall, as thoron concentration varies significantly at distances over $0.5 \mathrm{~m}$ from it.

In Canada, RADUETs were used in a preliminary survey of simultaneous radon and thoron measurements at 93 dwellings in Ottawa over a period of three months [48]. In this preliminary survey, the monitors were placed on the lowest floor (basement) of the house and at the distance of $\sim 0.5 \mathrm{~m}$ from the structure wall and the basement floor to increase thoron detection ability. Moreover, a survey of residential radon and thoron concentrations was conducted for three months in 2012-2013 fall/winter (October to March) periods at 3215 homes in 33 metropolitan areas, which covered $\sim 70 \%$ of the Canadian population [49]. Monitors were installed in the lowest lived-in level of the home where the member spends at least $4 \mathrm{~h}$ a day. Moreover, monitors were located on the wall at a height of $0.8-2.0 \mathrm{~m}$ from the floor and $\sim 0.5 \mathrm{~m}$ from the ceiling and $\sim 0.2 \mathrm{~m}$ from other objects so as to give normal airflow around them. Radon concentrations in this survey ranged from $7-2117 \mathrm{~Bq} \mathrm{~m}^{-3}$ with a mean of $104 \mathrm{~Bq} \mathrm{~m}{ }^{-3}$, whereas the thoron concentrations ranged from $<4-210 \mathrm{~Bq} \mathrm{~m}^{-3}$ with a mean of $8 \mathrm{~Bq} \mathrm{~m}^{-3}$. Furthermore, there was no correlation between indoor radon and thoron concentrations and thoron concentrations could not be predicted from widely available radon information.

In South Korea, the nationwide survey for radon and thoron was done using RADUETs in 2008-2009 at 1110 public buildings (schools and local governmental offices) [50]. The annual means of indoor radon and thoron concentrations were $61 \pm 2$ and $11 \pm 3 \mathrm{~Bq} \mathrm{~m}^{-3}$, respectively. Moreover, RADUETs were also used for quality control of the results in a complete survey on indoor radon concentration and the seasonal variation of indoor radon at all subway stations in Daejeon, in the central part of Korea in 2007-2008 [51]. The measurements were conducted quarterly for one year at three points: the ticket offices, ticket gates and platforms of each station. The monitors were placed more 
than $0.3 \mathrm{~m}$ from ceilings or walls and were not placed in the vicinity of air-conditioners, ventilation ducts and electrical devices to avoid effects that might be causes of heating or cooling, static electricity and thoron interference. The mean radon concentration of all the stations was $34 \pm 15 \mathrm{~Bq} \mathrm{~m}^{-3}$ (range from 9-98 $\mathrm{Bq} \mathrm{m}^{-3}$ ).

In Slovenia, RADUETs were used to study indoor radon and thoron concentrations in different environments [52]. The radon/thoron discriminative monitors were installed for two months at 2 dwellings, 7 kindergartens, 35 elementary schools, 4 hospitals, 9 spas and a karst cave; monitors were about $1.0 \mathrm{~m}$ away from a wall and $1.0-1.5 \mathrm{~m}$ above the floor. Radon and thoron ranges were 10-6870 and $<4-1361 \mathrm{~Bq} \mathrm{~m}{ }^{-3}$, respectively. The average ratio between indoor thoron concentrations and radon concentrations was 0.40. A radon and thoron survey in Slovenia indicated that thoron concentration in the environments was not negligible in comparison to radon concentration.

In Hungary, RADUETS were applied to investigate radon and thoron concentrations at 35 one-story dwellings near a closed uranium mine for 5- and 10-month long-term measurements [53], and 75 dwellings and 7 workplaces in 5 Hungarian counties for 3-month exposition periods [54]. In order to measure thoron, the RADUETs were placed mostly in inhabited areas of the houses, such as bedrooms and living rooms, at 1.0-1.5 m distance from the walls in the former study and at $0.15-0.20$ $\mathrm{m}$ distance from the walls in the latter study. The radon concentration of houses near the closed uranium mine was calculated by applying seasonal correction. The results showed that the mean radon concentration was $579 \mathrm{~Bq} \mathrm{~m}^{-3}$ (range: $37-2195 \mathrm{~Bq} \mathrm{~m}^{-3}$ ); in some cases, the thoron concentrations were not negligible and indicated that radon measurements which are sensitive to thoron could be misleading. However, the distribution of the mean radon concentration in five Hungarian counties was $79 \mathrm{~Bq} \mathrm{~m}^{-3}$ in 80 measurement places and below $100 \mathrm{~Bq} \mathrm{~m}^{-3}$ in 58 cases; only one case exceeded $200 \mathrm{~Bq} \mathrm{~m}{ }^{-3}$. The mean thoron concentration was $31 \mathrm{~Bq} \mathrm{~m}^{-3}$ (range: $1-285 \mathrm{~Bq} \mathrm{~m}^{-3}$ ). For about $10 \%$ of the measured rooms, the thoron concentration exceeded $100 \mathrm{~Bq} \mathrm{~m}^{-3}$. Consequently, it could be considered that the influence of thoron on the radiation dose might be considerable and therefore thoron measurements would be necessary.

In the Republic of Srpska, the thoron concentration was measured using RADUETs for 12 months in 25 primary schools of Banja Luka [55]. The monitors were deployed in one room of each school at a distance of $\sim 0.1 \mathrm{~m}$ from a wall, a height of $1.5-2.0 \mathrm{~m}$ above the floor and at least $0.5 \mathrm{~m}$ from the corners. The thoron concentrations were lower than $200 \mathrm{~Bq} \mathrm{~m}^{-3}$, mainly below $100 \mathrm{~Bq} \mathrm{~m}^{-3}$ (range: $7-198 \mathrm{~Bq} \mathrm{~m}^{-3}$ ) with a mean of $63 \pm 8 \mathrm{~Bq} \mathrm{~m}^{-3}$. The mean ratio between indoor thoron concentrations and radon concentrations was 0.68 .

In the Former Yugoslav Republic of Macedonia, the first national survey of indoor radon and thoron concentrations was performed with RADUETs in 300 dwellings during four consecutive 3-month periods for one year [56-58]. Devices were deployed in the living rooms or the bedrooms at a height of 1 to $1.5 \mathrm{~m}$ above the floor and $\geq 0.2 \mathrm{~m}$ from other objects and $>0.5 \mathrm{~m}$ from walls to ensure they were less sensitive to the distance effect from the walls. The mean values of indoor radon concentrations in winter, spring, summer and autumn were obtained to be $115,46,87$ and $92 \mathrm{~Bq} \mathrm{~m}^{-3}$, respectively. The maximum concentration of radon and an annual mean were $1276 \mathrm{~Bq} \mathrm{~m}^{-3}$ and $84 \pm 2 \mathrm{~Bq} \mathrm{~m}^{-3}$, respectively. The means of indoor thoron concentrations in winter, spring, summer and autumn were obtained as $90,56,30$ and $52 \mathrm{~Bq} \mathrm{~m}^{-3}$, respectively. The seasonal corrected annual mean concentrations ranged from $3-272 \mathrm{~Bq} \mathrm{~m}^{-3}$, with a mean of $28 \pm 2 \mathrm{~Bq} \mathrm{~m}^{-3}$.

In Serbia, the specific activities of radon and thoron were carried out using RADUETs at 63 dwellings in rural communities of Central Kosovo, North Kosovo and Prizren regions [59], and at 43 dwellings in Sokobanja municipality (southern Serbia) [60]. RADUETs were mainly placed in old houses without concrete floors that had been built using building materials from the local environment and they were placed in living rooms and bedrooms for three to five months by hanging on the walls to reduce the thoron measurement uncertainty. The mean indoor radon and thoron concentrations were $459 \mathrm{~Bq} \mathrm{~m}^{-3}$ (range: $14-1640 \mathrm{~Bq} \mathrm{~m}^{-3}$ ) and $128 \mathrm{~Bq} \mathrm{~m}^{-3}$ (range: $1-635 \mathrm{~Bq} \mathrm{~m}^{-3}$ ), respectively. In addition, RADUETs were deployed for measuring radon and thoron in soil gas [61] at 27 sites around Tent $B$ 
(southwest of Belgrade). The radon concentration in soil ranged from $0.8-25 \mathrm{kBq} \mathrm{m}^{-3}$, whereas the thoron concentration ranged from $0.6-1.9 \mathrm{kBq} \mathrm{m}^{-3}$.

In Romania, the radon/thoron survey was made at 35 schools in the northwestern region using RADUETs for a 3-month measurement period (covering spring) in a room located on the ground floor [62]. All monitors were positioned $\sim 0.3 \mathrm{~m}$ from the wall and $1.0 \mathrm{~m}$ above the floor, in consideration of the spatial distribution of thoron in the ground-floor room. The measured radon and thoron concentrations ranged from 31 to $414 \mathrm{~Bq} \mathrm{~m}^{-3}$ (mean: $215 \pm 10 \mathrm{~Bq} \mathrm{~m}^{-3}$ ) and below the detection limit to $235 \mathrm{~Bq} \mathrm{~m}^{-3}$ (mean: $70 \pm 3 \mathrm{~Bq} \mathrm{~m}^{-3}$ ), respectively.

In Ireland, RADUETs were used in 205 dwellings over a 3-month measurement period to monitor indoor thoron gas from 2007 to 2009 [63]. The monitors were suspended on a wall or another suitable surface in the living room and in the main bedroom. By fixing monitors on the wall, thoron concentrations drop rapidly with distance from its source in the walls or other room surfaces due to its short half-life. Thus, the maximum thoron concentration in a room could be obtained from this survey. The thoron concentration ranged from $<1-174 \mathrm{~Bq} \mathrm{~m}^{-3}$ with a mean of $22 \mathrm{~Bq} \mathrm{~m}{ }^{-3}$. The data are the actual measured concentrations and are not seasonally corrected.

The applications of RADUET to radon and thoron measurements in regional and nationwide surveys are summarized in Table 1. 
Table 1. Summary of the results obtained using RADUETs for radon and thoron surveys in various countries.

\begin{tabular}{|c|c|c|c|c|c|c|c|c|c|c|}
\hline \multirow{2}{*}{ Country } & \multirow{2}{*}{ Study Area } & \multicolumn{2}{|c|}{ Measuring Conditions } & \multicolumn{3}{|c|}{$\begin{array}{l}\text { Radon Concentrations } \\
\left(\mathrm{Bq} \mathrm{m}^{-3}\right)\end{array}$} & \multicolumn{3}{|c|}{$\begin{array}{l}\text { Thoron Concentrations } \\
\left(\mathrm{Bq} \mathrm{m}^{-3}\right)\end{array}$} & \multirow{2}{*}{ Reference } \\
\hline & & $\begin{array}{l}\text { Distance from } \\
\text { Wall (m) }\end{array}$ & $\begin{array}{l}\text { Distance from } \\
\text { Floor }(\mathrm{m})\end{array}$ & Min & Max & Mean & Min & Max & Mean & \\
\hline China & Yangxi and Yangdong & $\sim 0.3$ & $\sim 1.8$ & 27 & 476 & $124 \pm 78$ & 65 & 3957 & $1247 \pm 1189$ & {$[18,33]$} \\
\hline \multirow{2}{*}{ India } & Odisha & \multirow{2}{*}{$0.2-2.0$} & \multirow{2}{*}{$0.3-1.6$} & 2 & 333 & 91 & $<$ LLD * $^{*}$ & 1004 & 105 & {$[34]$} \\
\hline & Kerala & & & 1 & 21 & $6 \pm 4$ & 3 & 212 & $31 \pm 13$ & [35] \\
\hline Thailand & Chiang Mai & 0.2 & $1.0-2.0$ & 35 & 209 & $57 \pm 2$ & - & - & - & {$[40]$} \\
\hline \multirow{2}{*}{ South Korea } & Public building & - & - & - & 1004 & $61 \pm 2$ & - & - & $11 \pm 3$ & [50] \\
\hline & Subway station & $>0.3$ & - & 9 & 98 & $34 \pm 15$ & - & - & - & [51] \\
\hline \multirow{4}{*}{ Cameroon } & Poli & \multirow{4}{*}{0.5} & \multirow{4}{*}{$1.5-2.0$} & 46 & 143 & 82 & 24 & 238 & 94 & \multirow{4}{*}[24,36-39]{} \\
\hline & Lolodorf & & & 27 & 937 & 97 & 6 & 700 & 160 & \\
\hline & Betare-Oya & & & 88 & 282 & 133 & 4 & 383 & 92 & \\
\hline & Douala & & & 31 & 436 & 139 & 4 & 246 & 80 & \\
\hline Australia & North Queensland & $0.05-2.5$ & - & 60 & 390 & $140 \pm 55$ & 140 & 2600 & $1070 \pm 510$ & {$[47]$} \\
\hline Canada & Ottawa & $\begin{array}{l}\sim 0.5 \text { and } 0.2 \text { from } \\
\text { other objects }\end{array}$ & $\sim 0.5-2.0$ & 7 & 2117 & 104 & $<4$ & 210 & 8 & {$[48,49]$} \\
\hline Slovenia & - & 1.0 & $1.0-1.5$ & 10 & 6870 & - & 4 & 1361 & - & [52] \\
\hline Hungary & Closed uranium mine & $0-2.0$ & $1.0-1.5$ & 37 & 2195 & 579 & 1 & 285 & 31 & {$[53,54]$} \\
\hline Republic of Srpska & Banja Luka & $\begin{array}{l}\sim 0.1 \text { and } 0.5 \text { from } \\
\text { corners }\end{array}$ & $1.5-2.0$ & - & - & - & 7 & 198 & $63 \pm 8$ & [55] \\
\hline FYR Macedonia & - & $\begin{array}{l}>0.5 \text { and } \geq 0.2 \\
\text { from other objects }\end{array}$ & $1.0-1.5$ & - & 1276 & $84 \pm 2$ & 3 & 272 & $28 \pm 2$ & {$[56-58]$} \\
\hline Serbia & $\begin{array}{l}\text { Central Kosovo, North Kosovo, } \\
\text { Prizren and Southern Serbia }\end{array}$ & 0 & - & 14 & 1640 & 459 & 1 & 635 & 128 & {$[59,60]$} \\
\hline Romania & The north-western part & $\sim 0.3$ & 1.0 & 31 & 414 & $215 \pm 10$ & $<$ LLD * $^{*}$ & 235 & $70 \pm 3$ & [62] \\
\hline Ireland & - & 0 & - & - & - & - & $<1$ & 174 & 22 & [63] \\
\hline
\end{tabular}

${ }^{*}$ LLD $=$ Lower Limit of Detection. 


\section{Discussion}

Variations in reported values of indoor radon and thoron concentrations in the countries described in Section 3 can be clearly seen. These variations may be attributed to the construction materials and ventilation used, and the geological structures in different countries. However, it is important to note that for the nationwide and regional surveys on radon and thoron the sampled dwellings or places in each geographical area are selected in such a way as to be representative of the population of that geographical unit.

In this section, monitored rooms, geometry of the measurement space within the room, and the measurement period are briefly discussed on the basis of knowledge derived from the surveys in Section 3 which could provide a clearer understanding and roadmap for radon isotope measurements.

Monitored room: most of the RADUETs were located within the ground floors of inhabited rooms, such as living rooms, dining rooms, bedrooms and classrooms, in order to obtain a population representative of the distribution of radon and thoron concentration levels in each country.

Geometry of the measurement space within the room: radon is quite homogeneously distributed in a room [64]. Therefore, the position of the RADUETs for radon measurement can be chosen in many convenient ways, such as over a wardrobe or a bookcase, provided that it is exposed to indoor air. On the other hand, thoron concentration is not uniform in the room and decreases exponentially with the distance from the source [65]. The thoron results were quite high in surveys of China (max: $3954 \mathrm{~Bq} \mathrm{~m}^{-3}$ ), India (max: $1004 \mathrm{~Bq} \mathrm{~m}^{-3}$ ), Kenya (max: $1295 \mathrm{~Bq} \mathrm{~m}^{-3}$ ), Australia (max: $2600 \mathrm{~Bq} \mathrm{~m}^{-3}$ ), Hungary (max: $285 \mathrm{~Bq} \mathrm{~m}^{-3}$ ), Republic of Srpska (max: $198 \mathrm{~Bq} \mathrm{~m}^{-3}$ ), Serbia (max: $635 \mathrm{~Bq} \mathrm{~m}^{-3}$ ), Romania (max: $235 \mathrm{~Bq} \mathrm{~m}^{-3}$ ) and Ireland (max: $174 \mathrm{~Bq} \mathrm{~m}^{-3}$ ) due to placement of the RADUETs at distances less than $0.5 \mathrm{~m}$ from the wall. On the other hand, RADUETs were installed far from the wall $(\sim 0.5-1 \mathrm{~m})$ in surveys made in Canada, Slovenia and Cameroon so as to give normal airflow around them. Thus, the effect of the actual site selected should be taken into account when obtaining a representative value of indoor thoron. Moreover, the point of measurement should not be placed close to heating or cooling sources as was done in the South Korea survey to avoid the heat and cool effects on monitors.

Measurement period: the durations of radon and thoron measurements were for a single 2- and 3-month exposure period in Cameroon, Kenya, Australia, Canada, Slovenia, Romania and Ireland. Moreover, surveys in some countries used RADUETs placed for long-term measurements such as 5 and 10 months in Hungary, 6 months in China, 5 months in Serbia and 12 months in the Republic of Srpska. Additionally, shorter consecutive periods have also been adopted in Japan and the FYR of Macedonia (four consecutive 3-month periods) or in India and Thailand (two consecutive 6-month periods). However, it has to be pointed out that, for the time variations of radon and thoron concentrations and seasonal variations, the duration of measurements should be 12 months in total to obtain the annual mean. Besides, seasonal correction factors can be expressed as a function of the measurement period and the starting month [66]. In the case of radon surveys, the annual mean radon concentration estimated with a 3-month measurement and a seasonal correction factor has a higher uncertainty compared with 12-month measurement results, because seasonal variations can differ for different residences and the correction factors are based on mean seasonal variations $[67,68]$. Seasonal variations can differ for different countries as well as for different regions within a country. Thus, the seasonal correction should be estimated for radon and thoron concentrations in each region or country to evaluate the annual mean radon and thoron concentrations.

In Table 1 it can be observed that there are higher mean thoron levels than mean radon levels in Asia (China and India), Africa (Cameroon and Kenya) and Australia, whereas there are higher mean radon levels than mean thoron levels in Canada and Europe (Slovenia, Hungary, Serbia and Romania). Therefore, special attention should be paid to using the radon-thoron discriminative monitor in places with high thoron levels to obtain reliable and accurate results. Moreover, if devices which are somewhat sensitive to thoron are used for a nationwide or regional radon survey, the placement of the device should not be too close to walls suspected to have a considerable exhalation of thoron. 


\section{Conclusions}

In this paper the advantages of the radon-thoron discriminative monitor known as the RADUET were reviewed as well as the strategic plans for regional and national surveys in various countries. Most were regional surveys of indoor radon and thoron measurements; only Japan, Canada and South Korea carried out national surveys using RADUETs. Though most studies reported the data for indoor radon and thoron concentrations by RADUETs, the Japanese survey addressed only radon concentrations. The aim of using the RADUETs in the Japanese survey was to decrease the effect of thoron on the radon measurements. The indoor thoron measurement in many countries was as thoron exhalation from walls and other inside room surfaces due to the monitors being placed at a distance below $0.5 \mathrm{~m}$ from walls and room surfaces. Surveys of several countries measured mean radon and thoron concentrations in dwellings by placing RADUETs at distances of less than $0.5 \mathrm{~m}$ to $2.0 \mathrm{~m}$ away from walls.

In most instances and especially in high radiation areas, the results indicated that indoor radon concentrations would be much higher than reported if a non-discriminative detector was used. Moreover, the radiation doses produced by thoron cannot be neglected because sometimes it can be a more significant contributor than radon.

Studies in most countries installed the monitors in the bedroom or main living space of the residences, workplaces and schools for a period of at least two to three months. The actual duration of the measurements depended on the activity of radon and thoron in each area.

In particular, radon concentration in houses or buildings can vary and change swiftly due to several factors including seasonal changes. In this review, some researchers applied a seasonal correction factor for radon concentrations and only one suggested use of the correction factor from each season to estimate annual dose due to radon and thoron [57]. Therefore, thoron seasonal corrections, which are currently unknown and cannot be assumed to be as analogous to indoor radon seasonal corrections, should be studied.

This review detailed the importance of discriminative monitors for radon isotopes and their utilization in various countries. In addition, it can be used as a source of supporting data for regional and national surveys of radon and thoron measurement plans. It is very important to discriminate between radon and thoron signals for accurate radon measurement and for future risk assessment derived from internal exposure due to radon isotope inhalation.

Author Contributions: Conceptualization, C.K. and S.T.; methodology, C.K. and M.H.; validation, Y.T. and S.T.; formal analysis, C.K. and S.T.; investigation, C.K., Y.T., M.H. and S.T.; resources, C.K. and S.T.; data curation, C.K., Y.T. and M.H.; writing—original draft preparation, C.K. and Y.T.; writing—review and editing, C.K., Y.T., M.H. and S.T.; visualization, C.K.; supervision, C.K. and S.T.; project administration, M.H., Y.T. and S.T.; funding acquisition, S.T. All authors have read and agreed to the published version of the manuscript.

Funding: This research received no external funding.

Conflicts of Interest: The authors declare no conflict of interest.

\section{References}

1. World Health Organization. WHO Handbook on Indoor Radon: A Public Health Perspective; WHO: Geneva, Switzerland, 2009.

2. Darby, S.; Hill, D.; Auvinen, A.; Barros-Dios, J.M.; Baysson, H.; Bochicchio, F.; Deo, H.; Falk, R.; Forastiere, F.; Hakama, M.; et al. Radon in homes and risks of lung cancer: Collaborative analysis of individual data from 13 European case-control studies. BMJ 2005, 330, 223-227. [CrossRef] [PubMed]

3. International Commission on Radiological Protection. Lung Cancer Risk from Radon and Progeny and Statement on Radon; Annals of the ICRP: New York, NY, USA, 2010.

4. International Commission on Radiological Protection. Radiological Protection against Radon Exposure; Annals of the ICRP: New York, NY, USA, 2014.

5. International Commission on Radiological Protection. Occupational Intakes of Radionuclides: Part 3; Annals of the ICRP: New York, NY, USA, 2017. 
6. United Nations Scientific Committee on the Effects of Atomic Radiation. UNSCEAR 2006 Report, Effects of Ionizing Radiation. Volume I: Annex E Sources-to-Effects Assessment for Radon in Homes and Workplaces; UNSCEAR: NewYork, NY, USA, 2009.

7. Sanada, T.; Fujimoto, K.; Miyano, K.; Doi, M.; Tokonami, S.; Uesugi, M.; Tanaka, Y. Measurement of nationwide indoor Rn concentration in Japan. J. Environ. Radioact. 1999, 45, 129-137. [CrossRef]

8. Wang, Z.; Lubin, J.H.; Wang, L.; Zhang, S.; Boice, J.D., Jr.; Cui, H.; Zhang, S.; Conrath, S.; Xia, Y.; Shang, B.; et al. Residential radon and lung cancer risk in a high-exposure area of Gansu province, China. Am. J. Epidmiol. 2002, 155, 554-564. [CrossRef] [PubMed]

9. Wichman, H.E.; Rosario, A.S.; Heid, I.M.; Kreuzer, M.; Heinrich, J.; Kreienbrock, L. Increased lung cancer risk due to residential radon in a pooled and extended anlysis of studies in Germany. Health Phys. 2005, 88, 71-79. [CrossRef] [PubMed]

10. Krewski, D.; Lubin, J.H.; Zielinski, J.M.; Alavanja, M.; Catalan, V.S.; Field, R.W. A combined analysis of north Amarican case-control studies of residential radon and lung cancer. J. Toxicol. Environ. Health A 2007, 69, 533-597. [CrossRef] [PubMed]

11. Dowdall, A.; Murphy, P.; Pollard, D.; Fenton, D. Update of Ireland's national average indoor radon concentration-Application of a new survey protocol. J. Environ. Radioact. 2017, 169-170, 1-8. [CrossRef] [PubMed]

12. Park, T.H.; Kang, D.R.; Park, S.H.; Yoon, D.K.; Lee, C.M. Indoor radon concentration in Korea residential environments. Environ. Sci. Pollut. Res. 2018, 25, 12678-12685. [CrossRef] [PubMed]

13. Ivanova, K.; Stojanovska, Z.; Kunovska, B.; Chobanova, N.; Badulin, V.; Benderev, A. Analysis of the spatioal variation of indoor radon concentrations (national survey in Bulgaria). Environ. Sci. Pollut. Res. 2019, 26, 6971-6979. [CrossRef] [PubMed]

14. Tokonami, S.; Yang, M.; Sanada, T. Contribution from thoron on the response of passive radon detectors. Health Phys. 2001, 80, 612-615. [CrossRef] [PubMed]

15. Tokonami, S. Why is ${ }^{220} \mathrm{Rn}$ (thoron) measurement important? Radiat. Prot. Dosim. 2010, 141, $335-339$. [CrossRef] [PubMed]

16. Omori, Y.; Hosoda, M.; Takahashi, F.; Sanada, T.; Hirao, S.; Ono, K.; Furukawa, M. Japanese population dose from natural radiation. J. Radiol. Prot. 2020, in press. [CrossRef] [PubMed]

17. Fujimoto, K.; Kobayashi, K.; Uchiyama, M.; Doi, M.; Nakamura, Y. Nationwide indoor radon survey in Japan. Jpn. J. Health Phys. 1997, 32, 41-51. (In Japanese) [CrossRef]

18. Kudo, H.; Tokonami, S.; Omori, Y.; Ishikawa, T.; Iwaoka, K.; Sahoo, S.K.; Akata, N.; Hosoda, M.; Wanabongse, P.; Pornnumpa, C.; et al. Comparative dosimetry for radon and thoron in high background radiation areas in China. Radiat. Prot. Dosim. 2015, 167, 155-159. [CrossRef] [PubMed]

19. Akiba, S.; Tokonami, S.; Bochicchio, F.; McLaughlin, J.; Tommasino, L.; Harley, N. Thoron: Its metrology, health effects and implications for radon epidemiology: A summary of roundtable discussions. Radiat. Prot. Dosim. 2010, 141, 477-481. [CrossRef] [PubMed]

20. Tokonami, S.; Takahashi, H.; Kobayashi, Y.; Zhuo, W. Up-to-date radon-thoron discriminative detector for a large-scale survey. Rev. Sci. Instrum. 2005, 76, 113505. [CrossRef]

21. Omori, Y.; Tamakuma, Y.; Nugraha, E.D.; Suzuki, T.; Saputra, M.A.; Hosoda, M.; Tokonami, S. Impact of wind speed on response of diffusion-type radon-thoron detectors to thoron. Int. J. Environ. Res. Public Health 2020, 17, 3178. [CrossRef] [PubMed]

22. International Organization for Standards. Measurement of Radioactivity in the Environment-Air-Radon 220: Integrated Measurement Methods for the Determination of the Average Activity Concentration Using Passive Solid-State Nuclear Track Detectors ISO16641; ISO: Geneva, Switzerland, 2014.

23. Pornnumpa, C.; Oyama, Y.; Iwaoka, K.; Hosoda, M.; Tokonami, S. Development of radon and thoron exposure systems at Hirosaki University. Radiat. Environ. Med. 2018, 7, 13-20.

24. Bineng, G.S.; Saïdou; Tokonami, S.; Hosoda, M.; Tchuente Siaka, Y.F.; Issa, H.; Suzuki, T.; Kudo, H.; Bouba, O. The importance of direct progeny measurements for correct estimation of effective dose due to radon and thoron. Front Public Health 2020, 8, 17. [CrossRef] [PubMed]

25. Chen, J.; Rahman, N.; Atiya, I. Radon exhalation from building materials for decorative use. J. Environ. Radioact. 2010, 101, 317-322. [CrossRef]

26. Harley, N.; Chittaporn, P.; Medora, R.; Merrill, R. Measurement of the indoor and outdoor ${ }^{220}$ Rn (thoron) equilibrium factor: Application to lung dose. Radiat. Prot. Dosim. 2010, 141, 357-362. [CrossRef] [PubMed] 
27. Ramola, R.C.; Prasad, G.; Gusain, G.S.; Rautela, B.S.; Choubey, V.M.; Vidya Sagar, D.; Tokonami, S.; Sorimachi, A.; Sahoo, S.K.; Janik, M.; et al. Preliminary indoor thoron measurements in high radiation background area of southeastern coastal Orissa, India. Radiat. Prot. Dosim. 2010, 141, 379-382. [CrossRef] [PubMed]

28. Vaupotič, J.; Kávási, N. Preliminary study of thoron and radon levels in various indoor environments in Slovenia. Radiat. Prot. Dosim. 2010, 141, 383-385. [CrossRef] [PubMed]

29. Zhuo, W.; Chen, B.; Wei, M. Estimation of indoor ${ }^{220} \mathrm{Rn}$ progeny concentrations with ${ }^{220} \mathrm{Rn}$ measurements. Radiat. Prot. Dosim. 2010, 141, 408-411. [CrossRef] [PubMed]

30. Csordás, A.; Bátor, G.; Horváth, D.; Somlai, J.; Kovács, T. Validation of the scanner-based radon track detector evaluation system. Radiat. Meas. 2016, 87, 1-7. [CrossRef]

31. Iwaoka, K.; Hosoda, M.; Tabe, H.; Ishikawa, T.; Tokonami, S.; Yonehara, H. Activity concentration of natural radionuclides and radon and thoron exhalation rates in rocks used as decorative wall coverings in Japan. Health Phys. 2013, 104, 41-50. [CrossRef] [PubMed]

32. Sorimachi, A.; Tokonami, S.; Omori, Y.; Ishikawa, T. Performance test of passive radon-thoron discriminative detectors on environmental parameters. Radiat. Meas. 2012, 47, 438-442. [CrossRef]

33. Omori, Y.; Tokonami, S.; Ishikawa, T.; Sahoo, S.K.; Akata, N.; Sorimachi, A.; Hosoda, M.; Pornnumpa, C.; Wanabongse, P.; Kudo, H.; et al. A pilot study for dose evaluation in high-level natural radiation areas of Yangjiang, China. J. Radioanal. Nucl. Chem. 2015, 306, 317-323. [CrossRef]

34. Ramola, R.C.; Gusain, G.S.; Rautela, B.S.; Sagar, D.V.; Prasad, G.; Shahoo, S.K.; Ishikawa, T.; Omori, Y.; Janik, M.; Sorimachi, A.; et al. Levels of thoron and progeny in high background radiation area of southeastern coast of Odisha (India). Radiat. Prot. Dosim. 2012, 152, 62-65. [CrossRef] [PubMed]

35. Omori, Y.; Tokonami, S.; Sahoo, S.K.; Ishikawa, T.; Sorimachi, A.; Hosoda, M.; Kudo, H.; Pornnumpa, C.; Nair, R.R.K.; Jayalekshmi, P.A.; et al. Radiation dose due to radon and thoron progeny inhalation in high-level natural radiation areas of Kerala, India. J. Radiol. Prot. 2017, 37, 111-126. [CrossRef] [PubMed]

36. Saïdou; Tokonami, S.; Janik, M.; Bineng, G.S.; Abdourahimi; Ndjana Nkoulou, J.E. Radon-Thoron discriminative measurements in the high natural radiation areas of Southwestern Cameroon. J. Environ. Radioact. 2015, 150, 242-246.

37. Saïdou; Tokonami, S.; Patrice, E.A. Natural radiation survey in the uranium and thorium bearing regions of Cameroon. Radiat. Environ. Med. 2016, 5, 53-58.

38. Tokonami, S.; Hosoda, M.; Joseph Emmanuel, N.N.; Akata, N.; Flore, T.S.Y.; Modibo, O.B.; Samuel, B.G.; Didier, T.S.S. Natural radiation exposure to the public in mining and ore bearing regions of Cameroon. Radiat. Prot. Dosim. 2019, 184, 391-396.

39. Didier, T.S.; Tokonami, S.; Hosoda, M.; Suzuki, T.; Kudo, H.; Bouba, O. Simultaneous measurements of indoor radon and thoron and inhalation dose assessment in Douala City, Cameroon. Isotopes. Environ. Health. Stud. 2019, 55, 499-510. [CrossRef] [PubMed]

40. Autsavapromporn, N.; Klunklin, P.; Threeratana, C.; Tuntiwechapikul, W.; Hosoda, M.; Tokonami, S. Short telomere length as a biomarker risk of lung cancer development induced by high radon levels: A pilot study. Int. J. Environ. Res. Public Health. 2018, 15, 2152. [CrossRef] [PubMed]

41. Suzuki, G.; Yamaguchi, I.; Ogata, H.; Sugiyama, H.; Yonehara, H.; Kasagi, F.; Fujiwara, S.; Tatsukawa, Y.; Mori, I.; Kimura, S. A nationwide survey on indoor radon from 2007 to 2010 in Japan. J. Radiat. Res. 2010, 51, 683-689. [CrossRef] [PubMed]

42. Doi, M.; Fujimoto, K.; Kobayashi, S.; Yonehara, H. Spatial distribution of thoron and radon concentrations in the indoor air of a traditional Japanese wooden house. Health Phys. 1994, 66, 43-49. [CrossRef] [PubMed]

43. Hosoda, M.; Kudo, H.; Iwaoka, K.; Yamada, R.; Suzuki, T.; Tamakuma, Y.; Tokonami, S. Characteristic of thoron $\left({ }^{220} \mathrm{Rn}\right)$ in environment. Appl. Radiat. Isot. 2017, 120, 7-10. [CrossRef] [PubMed]

44. Nyambura, C.; Tokonami, S.; Hashim, N.O.; Chege, M.W.; Suzuki, T.; Kudo, H.; Hosoda, M. Annual effective dose assessment due to radon and Thoron progenies in dwellings of Kilimambogo, Kenya. Radiat. Prot. Dosim. 2019, 184, 430-434. [CrossRef] [PubMed]

45. Chege, M.W.; Hashim, N.O.; Merenga, A.S.; Meisenberg, O.; Tschiersch, J. Estimation of annual effective dose due to radon and thoron concentrations in mud dwellings of Mrima Hill, Kenya. Radiat. Prot. Dosim. 2015, 167, 139-142. [CrossRef] [PubMed] 
46. Chege, M.; Hashim, N.; Nyambura, C.; Mustapha, A.; Hosoda, M.; Tokonami, S. Radon and Thoron; Radioactive gases lurking in earthen houses in rural Kenya. Front Public Health 2019, 7, 113. [CrossRef] [PubMed]

47. Kleinschmidt, R.; Watson, D.; Janik, M.; Gillmore, G. The presence and dosimetry of radon and thoron in a historical, underground metalliferous mine. J. Sust. Min. 2018, 17, 120-130. [CrossRef]

48. Chen, J.; Tokonami, S.; Sorimachi, A.; Takahashi, H.; Falcomer, R. Results of simultaneous radon and thoron tests in Ottawa. Radiat. Prot. Dosim. 2008, 130, 253-256. [CrossRef] [PubMed]

49. Chen, J.; Bergman, L.; Falcomer, R.; Whyte, J. Results of simultaneous radon and thoron measurements in 33 metropolitan areas of Canada. Radiat. Prot. Dosim. 2015, 163, 210-216. [CrossRef] [PubMed]

50. Kim, Y.; Chang, B.U.; Park, H.M.; Kim, C.K.; Tokonami, S. National radon survey in Korea. Radiat. Prot. Dosim. 2011, 146, 6-10. [CrossRef] [PubMed]

51. Yoon, S.; Chang, B.U.; Kim, Y.; Byun, J.I.; Yun, J.Y. Indoor radon distribution of subway stations in a Korean major city. J. Environ. Radioact. 2010, 101, 304-308. [CrossRef] [PubMed]

52. Vaupotič, J.; Kávási, N. Radon and thoron doses in kindergartens and elementary schools. Radiat. Prot. Dosim. 2012, 152, 247-252. [CrossRef] [PubMed]

53. Nemeth, C.; Jobbagy, V.; Kavasi, N.; Somlai, J.; Kovacs, T.; Tokonami, S. Radon and Thoron parallel measurements in dwellings nearby a closed Hungarian uranium mine. Nukleonika 2010, 55, 459-462.

54. Szeiler, G.; Somlai, J.; Ishikawa, T.; Omori, Y.; Mishra, R.; Sapra, B.K.; Mayya, Y.S.; Tokonami, S.; Csordás, A.; Kovács, T. Preliminary results from an indoor radon thoron survey in Hungary. Radiat. Prot. Dosim. 2012, 152, 243-246. [CrossRef] [PubMed]

55. Ćurguz, Z.; Stojanovska, Z.; Žunić, Z.S.; Kolarž, P.; Ischikawa, T.; Omori, Y.; Mishra, R.; Sapra, B.K.; Vaupotič, J.; Ujić, P.; et al. Long-term measurements of radon, thoron and their airborne progeny in 25 schools in Republic of Srpska. J. Environ. Radioact. 2015, 148, 163-169. [CrossRef] [PubMed]

56. Stojanovska, Z.; Bossew, P.; Tokonami, S.; Žunić, Z.S.; Bochicchio, F.; Boev, B.; Ristova, M.; Januseski, J. Indoor thoron concentration in FYR of Macedonia. Radiat. Meas. 2013, 49, 57-66. [CrossRef]

57. Stojanovska, Z.; Zunic, Z.S.; Bossew, P.; Bochicchio, F.; Carpentieri, C.; Venoso, G.; Mishra, R.; Rout, R.P.; Sapra, B.K.; Burghele, B.D.; et al. Results from time integrated measurements of indoor radon, thoron and their decay product concentrations in schools in the Republic of Macedonia. Radiat. Prot. Dosim. 2014, 162, 152-156. [CrossRef] [PubMed]

58. Stojanovska, Z.; Januseski, J.; Bossew, P.; Zunic, Z.S.; Tollefsen, T.; Ristova, M. Seasonal indoor radon concentration in FYR of Macedonia. Radiat. Meas. 2011, 46, 602-610. [CrossRef]

59. Milic, G.; Jakupi, B.; Tokonami, S.; Trajkovic, R.; Ishikawa, T.; Celiković, I.; Ujic, P.; Cuknic, O.; Yarmoshenko, I.; Kosanovic, K.; et al. The concentration and exposure doses of radon and thoron in residents of the rural areas of Kosovo and Metohija. Radiat. Meas. 2010, 46, 129-131.

60. Mishra, R.; Zunic, Z.S.; Venoso, G.; Bochicchio, F.; Stojanovska, Z.; Carpentieri, C.; Prajith, R.; Sapra, B.K.; Mayya, Y.S.; Ishikawa, T.; et al. An evaluation of thoron (and radon) equilibrium factor close to walls based on long-term measurements in dwellings. Radiat. Prot. Dosim. 2014, 160, 164-168. [CrossRef] [PubMed]

61. Žunić, Z.S.; Janik, M.; Tokonami, S.; Veselinović, N.; Yarmoshenko, I.V.; Zhukovsky, M.; Ishikawa, T.; Ramola, R.C.; Ciotoli, G.; Jovanović, P.; et al. Field experience with soil gas mapping using Japanese passive radon/thoron discriminative detectors for comparing high and low radiation areas in Serbia (Balkan Region). J. Radiat. Res. 2009, 50, 55-61. [CrossRef] [PubMed]

62. Burghele, B.D.; Cosma, C. Thoron and radon measurements in Romanian schools. Radiat. Prot. Dosim. 2012, 152, 38-41. [CrossRef] [PubMed]

63. McLaughlin, J.; Murray, M.; Currivan, L.; Pollard, D.; Smith, V.; Tokonami, S.; Sorimachi, A.; Janik, M. Long-term measurements of thoron, its airborne progeny and radon in 205 dwellings in Ireland. Radiat. Prot. Dosim. 2011, 145, 189-193. [CrossRef] [PubMed]

64. Cigna, A.A.; Badino, G. Comment on Al-Azmi et al. Health Phys. 2008, 95, 255-256. [CrossRef] [PubMed]

65. Urosevic, V.; Nikezic, D.; Vulovic, S. A theoretical approach to indoor radon and thoron distribution. J. Environ. Radioact. 2008, 99, 1829-1833. [CrossRef] [PubMed]

66. Pinel, J.; Fearn, T.; Darby, S.C.; Miles, J.C.H. Seasonal correction factors for indoor radon measurements in the United Kingdom. Radiat. Prot. Dosim. 1995, 58, 127-132. 
67. Baysson, H.; Billon, S.; Laurier, D.; Rogel, A.; Tirmarche, M. Seasonal correction factors for estimating radon exposure in dwellings in France. Radiat. Prot. Dosim. 2003, 104, 245-252. [CrossRef] [PubMed]

68. Clife, K.D.; Miles, J.C.H.; Naismith, S.P. False positive and false negative radon measurement results due to uncertainties in seasonal correction factors. Radiat. Prot. Dosim. 1994, 56, 291-292. [CrossRef]

(C) 2020 by the authors. Licensee MDPI, Basel, Switzerland. This article is an open access article distributed under the terms and conditions of the Creative Commons Attribution (CC BY) license (http://creativecommons.org/licenses/by/4.0/). 